\title{
The Accounting Harmonization Process: Italian Public Principles and International Accounting Standards. Is It a Cultural Choice?*
}

\author{
Roberto Jannelli ${ }^{1}$, Cristina Tesone ${ }^{2}$ \\ ${ }^{1}$ Aggregate Professor of Public Accounting, University of Sannio and Partner KPMG, \\ Government and Public sector, Italy \\ ${ }^{2}$ Consultant KPMG, Government and Public sector, Italy \\ Email: jannelli@unisannio.it, ctesone@kpmg.it
}

Received July 19, 2013; revised August 22, 2013; accepted September 2, 2013

Copyright (C 2013 Roberto Jannelli, Cristina Tesone. This is an open access article distributed under the Creative Commons Attribution License, which permits unrestricted use, distribution, and reproduction in any medium, provided the original work is properly cited.

\begin{abstract}
The aim of this paper is to evaluate the complex process of Accounting Harmonization, which involves the Italian Public Administration and the pressure to have a more transparent information system for the development of suitable accountability and comparability. Additionally, the paper examines the degree of diffusion of the IPSAS, the main characteristics of these principles and the difficulties face implementing them. These difficulties, lead to the creation of a set of European Public Sector Accounting Standards (EPSAS). The introduction of the new accounting rules is intended to facilitate the comparability of financial statements and improve the quality and transparency of economic and financial information, favouring the increase of efficiency and integration, at least at a European level. The investigation of this paper supports the theory that before selecting the best principles to apply, it is necessary to make a cultural choice.
\end{abstract}

Keywords: IPSAS; EPSAS; Accrual Basis of Accounting; Cash Basis of Accounting; Public Accounting Reform; Cultural Choice

\section{Research of Methodology, Main Findings and Implication}

The analysis of the accounting harmonization process was primarily realized by examining the current Italian Public Accounting Reform, which required a uniform classification of the reports and accounting principles at Central, Regional and Local level. From a methodological point of view, we wanted to analyze whether the Italian public accounting system, adjusted by the new regulations, is compliant with the international harmonization process. To reach this goal, we need to evaluate how accrual accounting has been introduced in the Italian public sector by means of a "step by step" accounting harmonization process. This paper's second objective is to examine the characteristics, the application procedures, the criticalities and the evolving perspectives of a set of International/European accounting principles both in Italy and in the other Member States.

"In this joint research, paragraphs 1, 2, 3.1 and 4 are developed by R. Jannelli; paragraph 3.2 is developed by C. Tesone.

\section{Italian Public Sector Accounting: From the Recent Reforms towards the Accrual Basis}

The evolution of accounting systems and the harmonization process has been a subject under discussion for many years: for example Cavour, a 19th Century Italian Prime Minister, stated that "shaping Italy, merging the elements it is composed of, harmonizing the North and the South, presents as many difficulties as a war against Austria or a battle with Rome". It is from the spirit of that statement that we can deduce that harmonization, in a broad sense, is anything but an easy target to accomplish, and is certainly not a topic that has arisen in modern times [1]. The difficulties that lie within the harmonization process go beyond accounting: to achieve a harmonious system of public administration then government choices, governance models, operating rules and the entire decision-making mechanisms and management system [2] would need to be harmonized.

Focusing our analysis on accounting themes, it is therefore necessary to start from the gradual unification 
process of the Italian States (1861), when it became clear that an accounting model and a financial statement structure capable of summarizing and aligning the various accounting models from the different States was necessary [3]. The above mentioned national necessity has become primarily European-the economic integration in the "eurozone" means that public administration entities have to interact in a social-economic scene that crosses over the old national boundaries and leads to the free mobility of assets, persons and finance [4]. Now, the financial crisis has strengthened the Global interdependency among countries and has ungraded this harmonization necessity to an international level $[5,6]$.

Therefore, a radical transformation of National, European and International economic-financial information is necessary to achieve a standardized accounting language [7].

The latter is a key element to achieve the harmonization intended as it is a complex process made up of procedures, principles, rules, models and glossaries aimed at making the accounting summary documents comparable and clear [8].

In this paper, we have attempted to analyze the accounting harmonization following 4 typologies of perspectives: internal, external, global and unitary.

In this paragraph, we have examined the internal and external harmonization. For the global and unitary versions, please refer to the following paragraph.

The goal of Internal Harmonization is to favour a horizontal reading of Public Reports, overcoming the current fragmentation caused by the adoption of different criteria between different levels of Italian public administration. In Italy, the Public Administration system is in itself complex both for the large number of laws and regulations and for the structural characteristics of different government levels. In this paper, taking into consideration the objectives and the conciseness requested, it is not possible to precisely reconstruct all the laws \& regulations, but we have just mentioned the most recent regulations, confining our analysis to Central, Regional and Local Authorities.

In particular, we focused our analysis on the combined order of law on fiscal federalism ${ }^{1}$ (2009), the bill of reform of public accounting ${ }^{2}$ (2009), the relative legislative decrees $^{3}$ (2011) and of the main National and European Accounting principles (SEC 95). These regulations are driven by the same purpose, which is the development of an integrated accounting system suitable for the consolidation of public accounts [9-11] also in a European per-

\footnotetext{
${ }^{1}$ Law 5 May 2009, n. 42 "Delega al Governo in materia di federalismo fiscale, in attuazione dell'articolo 119 della Costituzione".

${ }^{2}$ Law 31 December 2009, n. 196 "Legge di contabilità e finanza pubblica”.

${ }^{3}$ Legislative Decree 118/2011 and Legislative Decree 91/2011.
}

spective. The two legislations: the bill of reform of public accounting and the law on fiscal federalism have different application areas, the central public administration, and the local government, respectively.

In particular, the law for the central administration (2009) aims at satisfying the economic and financial demands of the European Union (EU) and at the same time at guaranteeing a high level of transparency and veracity of the communication offered to stakeholders. The opportunity to widen the area of application, beyond national borders, could be attributed to the evolution of European rules in the context of the Stability Pact [1]. Another important innovation foreseen, by the cited law, is the innovative structure of "the Annual financial budget (forecast) adopted by all the public administrations that have to be articulated according to missions and programs (art. 2, comma 2, letter c), coherent with the economical and functional classifications expected by the European community rules for National Accounting” (Classification of Function of Government adopted as a standard by ESA 95). The latter represents the attempt to observe European demands in view of an External harmonization. Additionally, with reference to the type of accounting systems, the legislative provision for central administration (2011) foresees the strengthening of the planning rule of a cash basis balance in a mixed system "cash and accrual accounting”. At present, the last harmonization decree (2011) envisaged the provision of a unitary accounting system combining accrual-basis and financial-basis accounting to enrich financial reporting, increasing the orientation towards accountability and transparency.

The accounting structure of the Italian Regions prereform, was of a financial nature, with a balance revised in terms of competence based on an authorizational process and cash basis methodology (2000), while, the Local governments used a financial accounting system supported, in the reporting stages, by the typical statements of accrual basis methodology (2000). In this context, the last harmonization decree, for the Regional and Local governments, represented the attempt to overcome the "accounting federalism" condition that characterizes the Italian public sector [12]. In recognizing the "regionality" of our State, the Constitution draws attention to the need of founding the relationship among the central administration and local autonomies [13] not on separation but on cooperation and harmonization, protecting collective administrative interests [14].

The recent public accounting system reform reveals, therefore, signs of important innovation: an integrated accounting system that guarantees the collection of data both under a financial and an economic profile, in line with the new role that the Public Administration has in the social and economic context [15]. The accounting 
system focused only on the financial nature of operations recorded, it was not suitable to represent the other aspects of said operations such as their patrimonial and economical equilibrium [3]. The most important element of the current legislation is the provision mandated to "enhance" the principle of financial competence. The principle foresees that the cash element prevails over the entitlement element, which is considered separately, assuming that the recognition of obligations occurs when they arise, but it affects the financial statement according to their due time (payment term). This choice seems to position the financial accounting system closer to the accrual basis method, representing another effort from our legislator to move towards an accrual accounting logic.

Table 1 gives an overview of the complex apparatus of the Italian Public Administration accounting systems.

In conclusion, the goal of the various regulations has been represented by the integration of the financial statement representation, which, before the reform, emphasized the financial aspects by overcoming the other economical-patrimonial aspects.

Despite several attempts of the legislature by means of the 2011 reform, on the transition of Italian public accounting to a complete accrual-based accounting system, we must not forget that the accounting system that prevails in Italy, at various government levels, is the financial accounting system. Therefore, the Italian system could hamper the IPSAS/EPSAS diffusion, principles that are mostly based on the accrual basis of accounting. Nonetheless, the recent path set forth by the legislative innovations gives us hope for a forward-oriented International/European logic where the accrual basis of accounting ascends as a key element [16-19].

\section{The International Public Sector Accounting Standard: Characteristics, Application Procedures, Criticalities and Evolving Perspectives in Italy and in the Other Member States}

\subsection{Suitability of the International Public Sector Accounting Standard}

The growing economic interdependency between Countries means that the economic politics of one Country have repercussions on other States, at the same time internal actions are modified by actions undertaken elsewhere [20].

This is precisely the case for Italy and the other countries of the Eurozone, that for reasons imputable to the recent financial crisis, they have strongly increased their interdependency and the interdependency with other non EU Countries, leading to a need for a global exchange of views. The global harmonization of the accounting systems would play a decisively powerful role [21,22]. The importance of the theme goes over and beyond the reality of the Italian Public Administration involved in the reform process.

It is of prime importance that the Council Directive 2011/85/EU assigned the task of evaluating, by the end of 2012, the suitability of the international accounting principles applicable to the public sector (IPSAS) for

Table 1. An overview of italian public administration accounting systems*.

\begin{tabular}{|c|c|c|c|c|}
\hline Category & $\begin{array}{l}\text { Main accounting } \\
\text { system }\end{array}$ & $\begin{array}{l}\text { Accounting system } \\
\text { secondary }\end{array}$ & $\begin{array}{l}\text { Relevant legislation and } \\
\text { accounting standards }\end{array}$ & Report system \\
\hline \multicolumn{5}{|c|}{ LOCAL AUTHORITIES } \\
\hline - Central & $\begin{array}{l}\text { System based on } \\
\text { financial basis of } \\
\text { accounting }\end{array}$ & $\begin{array}{l}\text { Accrual system of } \\
\text { accounting-in addition } \\
\text { to financial basis of } \\
\text { accounting }\end{array}$ & $\begin{array}{ll}\text { - } & \text { Law. 196/2009; } \\
\text { - } & \text { Leg. Decree. 91/2011; } \\
\text { - } & \text { COFOG. }\end{array}$ & $\begin{array}{l}\text { - } \text { Annual financial budget (forecast); } \\
\text { - } \text { (forecast); } \\
\text { - } \text { Financial Statement } \\
\text { - Consolidated financial statements }\end{array}$ \\
\hline - Regional & $\begin{array}{l}\text { System based on } \\
\text { financial basis of } \\
\text { accounting }\end{array}$ & $\begin{array}{l}\text { Accrual system of } \\
\text { accounting-in addition } \\
\text { to financial basis of } \\
\text { accounting }\end{array}$ & $\begin{array}{ll}\text { - } & \text { Law 42/2009; } \\
\text { - } & \text { Leg. Decree 118/2011; } \\
\text { - } & \text { COFOG; } \\
\text { - } & \text { DPCM 28/12/2011; } \\
\text { - } & \text { Italian civil code for accrual } \\
& \text { Accounting }\end{array}$ & $\begin{array}{l}\text { - } \quad \text { Annual financial budget (forecast); } \\
\text { - } \quad \text { Budget multi-annual financial } \\
\text { (forecast); } \\
\text { - } \quad \text { Financial Statement } \\
\text { - } \quad \text { Consolidated financial statements. }\end{array}$ \\
\hline - Local Goverment & $\begin{array}{l}\text { System based on } \\
\text { financial basis of } \\
\text { accounting }\end{array}$ & $\begin{array}{l}\text { Accrual system of } \\
\text { accounting-in addition } \\
\text { to financial basis of } \\
\text { accounting }\end{array}$ & $\begin{array}{l}\text { - } \quad \text { Law 42/2009; } \\
\text { - } \text { Leg. Decree 118/2011; } \\
\text { - } \text { COFOG; } \\
\text { - } \quad \text { DPCM 28/12/2011; } \\
\text { - } \quad \text { Italian civil code for accrual } \\
\text { Accounting }\end{array}$ & $\begin{array}{l}\text { - } \text { Annual financial budget (forecast); } \\
\text { - } \text { Budget multi-annual financial; } \\
\text { - } \quad \text { Financial Statement; } \\
\text { - } \quad \text { Consolidated financial statements }\end{array}$ \\
\hline
\end{tabular}

Source: Our elaboration; ${ }^{*}$ This table includes the main categories of theItalian public administration system. 
Member States to the Commission and that, in implementing this legislation, a public consultation was realized and managed by EUROSTAT ${ }^{4}$. The Council directive 2011/85/EU (the Budgetary Frameworks Directive) emphasizes that it unanimously believes that it is crucial to have complete and reliable reports comparable among Member States. As already stated, the recent financial crisis has highlighted the need for increased transparency of governments' reports, therefore demanding greater public accountability and clearer evidence of the financial stability of each country.

The recent Greek and Cypriot government-debt crisis highlighted the failure of those statistical systems implemented to reduce the State risk dissemination on other data, leading to the realization that the structural management of the Eurozone and the entire European Union needs reinforcing $[23,24]$.

The Commission has developed, adopting a package of 6 legislative proposals (six-pack), a package for the European economic governance, shown in Table 2.

Article 3 of Directive 2011/85/EU requires Member States to "have in place public accounting systems comprehensively and consistently covering all sub-sectors of general government and containing the information needed to generate accrual data with a view to preparing data based on the ESA 95 standard" (Report from the Commission to the Council and the European Parliament). It emphasizes the intrinsic misalignment of public sector account practices and EU practices, as they are based on the record of cash flows and ESA 95 accrual data respectively. Eurostat believes that only through a system of harmonized principles of accrual basis accounting can such a "statistical asymmetry" 5 be overcome.

Without doubt, only the development of information at a microeconomic level, harmonized to the principles of accrual basis accounting [25] for all entities of the public sector in all the EU member states, would be able to guarantee the quality of information concerning debt and deficit. The improvement of the accounting systems is an element capable of making communication clear and timely, in a stakeholder oriented model that forces the public companies to fix as their objective the evaluation of their own performances from the point of view of comparison with the other Public Administrations, which can be National, European and Continental [26].

IPSASs, the only principles used at an international level, are set by an international organization (IPSAS)

\section{${ }^{4} \mathrm{Cfr}:$}

http://epp.eurostat.ec.europa.eu/cache/ITY_PUBLIC/D4_2012/EN/D4 2012-EN.PDF Public consultation-Assessment of the suitability of the International Public Sector Accounting Standards for the Member States, Luxembourg, 18 December 2012.

${ }^{5}$ Font: EC Report "Towards implementing harmonised public sector accounting standards in Member States. The suitability of IPSAS for the Member States".
Table 2. European economic governance package (referred to as the "six-pack").

\begin{tabular}{l} 
Fiscal policy \\
\hline 1) Regulation of the European Parliament and the Council \\
amending Regulation (EC) No 1466/97 on the strengthening of \\
budgetary surveillance and coordination of economic policies \\
2) Council Regulation amending Regulation (EC) No 1467/97 \\
regarding speeding up and clarifying the implementation of the \\
excessive deficit \\
3) Regulation of the European Parliament and Council Directive on \\
the effective enforcement of budgetary surveillance in the euro area \\
4) Directive of the Council on the requirements for the fiscal \\
framework of the Member States \\
\hline Macroeconomic imbalances \\
5) Regulation of the European Parliament and of the Council on the \\
prevention and correction of macroeconomic imbalances \\
6) Regulation of the European Parliament and of the Council on \\
enforcement action to correct excessive macroeconomic imbalances \\
in the euro area
\end{tabular}

Font: Official website of the European Union.

that is not linked to any particular geographical area, and supplies technical tools that allow for improvement of the accountability of "all public sector entities" [27,28].

The key principles which come from the International Public Sector Accounting Standards Board (IPSASB) are:

- The need to have homogeneous principles for all public administration sectors in each country;

- The inclination of setting standards that follow the Accrual Basis of Accounting. Currently there are 32 IPSAS Full Accrual Basis Accounting in place, and only one Cash Accounting based IPSAS, which is addressed to those subjects that have a future intention of adopting the Accrual Basis of accounting. This tendency is confirmed by the project for the implementation of an ad-hoc Conceptual Framework based on Accrual accounting [29]. In any case, it is worthwhile making a distinction: Cash Accounting is very different to the Italian style Juridical Accounting, which finds its natural expression in the forecast system [30,31]. Based on the above, a forecast is the instrument used to identify the maximum amount of outflows (defined on the basis of realizable receipts) on which the future activities of the Public Administration are planned. Likewise, in the case of the full accrual basis of accounting implementation, in Italy it would not be applicable in all of its parts. As Onida affirmed, there are many notions on both "financial competency" and "economic competency [11,28]". It is important to highlight that the IPSAS do not allow for mixed accounting systems but it only allows for either accrual or cash accounting. 
The Eurostat analysis on the state of application of the international principles in the 15 Member States shows the following results:

- 5 Member States make reference to the IPSAS in the development of their financial reporting;

- 9 Member States have based their national accounting principles on the IPSAS or have created principles compliant with IPSAS;

- 1 Member State has applied IPSAS to some sectors of local administration.

It can be concluded, therefore, that despite the potential benefits that can be derived from fully applying the principles, no Member State has opted for an integral application. The absence of complete adherence to these principles, taking into consideration the answers provided by the 68 stakeholders interviewed by Eurostat, derives from the fact that, although the IPSASs represent an unquestionable reference for accounting harmonization on a European level, they cannot be adopted without considering the specific administrative political system, juridical order and Governance system of each country. Additionally, the elevated flexibility of the IPSAS principles, allowing for alternative accounting treatment for the evaluation of financial statement items, could reduce the comparability and harmonization of the various financial statements. Then, we must highlight the scarce contextualization in respect to public reality. It cannot be forgotten that the IPSAS were derived and adopted from principles created for companies.

\subsection{Is Europe Ready for EPSAS ${ }^{6}$ ?}

Starting from the applicative difficulties mentioned above, and in consideration of the already cited public consultation, the possibility emerged of the development of a specific set of European accounting principles for the public sector (European Public Sector Accounting Standards-EPSAS), for which the IPSAS [32-34] can represent the framework of reference. The current impossibility of global harmonization of the EU countries represents a push towards Unitary Harmonization. The EPSAS accounting principles seem to offer remedies to some of the issues previously raised, indeed they facilitate the implementation process, which is quite simple and rapid to do, and they meet several different shared needs of the Member States.

Just as the IPSAS do, they provide for a system that guarantees the reliability of the data produced, but in order to accomplish a sound set of harmonized accounting principles it is necessary to encourage the implementtation of vigorous political support, the availability of

${ }^{6}$ Font: EC Report "Towards implementing harmonised public sector accounting standards in Member States. The suitability of IPSAS for the Member States". human resources and integrated information systems, the capability of public administration to administer a more complex accounting system and the existence of an efficient internal control and external audit of public accounting. There are additional requirements for the Member States that use cash accounting (i.e. Italy). The evaluation, adoption and application of the EPSAS will take place gradually and will require the planning of a common base of European accounting principles for the public sector, in view of their integration in a regulation framework proposal. If all changes are to be effective, a gradual approach and awareness of the local and national realities is indispensable. This result is certainly not possible through a single legislative action but it requires several ad hoc adjustments to be made along the way. Additionally, it is worthwhile making a precise evaluation of costs and innate benefits of reaching such objectives, both on a European and on an international scale. Regarding the costs, they mainly depend on the extension and complexity of the public sectors of each country, and the completeness and reliability of existing accounting systems. As for the benefits, they are summarized in the well known principles of governance, transparency and responsibility. Consequently, cash-based systems become difficult to accept, especially, in this period that suffers from financial market instability and uncertainty of future economic developments, which justifies the existence of the security network granted to the Member States to use economic support measures in case of deep crisis (article 107, paragraph 3 , letter b, of the treaty TCE).

For the above consideration, also in Italy, it is necessary to have an accounting systems that not only allow for political justification of expenses and revenue but to move towards systems aimed at reinforcing empowerment of the use of public resources in respect of the community, allowing for supervision of the entire public wealth [35]. Only when we reach such results, we will be able to consider common principles for the EU and on an International scale.

\section{Conclusions}

In this paper, we refrain from affirming which is the best accounting system and, consequently, which are the best standards to use to reach an adequate level of transparency of public information.

Indeed, the change must have cultural roots in order to lead to the application of the most suitable accounting system.

To make this change possible, it is necessary that those who work in the Public Administration sector realize that they are actually managing a company. Therefore, a good manager should always apply the best managing methodology, no matter if he works for a public or a private 
company.

Based on this realization, primary attention should be given to the accounting systems methodology reassessment to make the revised accounting systems more efficient. The awareness on this matter should not be constrained just to Italy, but should also be spread around Europe.

An individual being a part of the EC comes from being aware of sharing the feeling of being European. This feeling, in a way allows us to remember what Goethe wrote about in his interpretation of "Elective Affinities".

\section{REFERENCES}

[1] L. D’Alessio, “Logiche e Criteri di Armonizzazione Nelle Recenti Normative di Riforma Della Contabilità Pubblica,” Azienda Pubblica, Vol. 25, No. 1, 2012, pp. 23-39.

[2] P. Ricci, "Il Potenziale Impatto delle Nuove Disposizioni Contabili sui Comportamenti Aziendali e sul Sistema Economico,” Azienda Pubblica, Vol. 25, No. 1, 2012, pp. 41-51

[3] L. Anselmi, A. Pavan and E. Reginato, "Cassa, Competenza Finanziaria e Competenza Economica: La Scelta Delle Basi Contabili in un Sistema Armonizzato di Contabilità Pubblica,” Azienda Pubblica Azienda Pubblica, Vol. 25, No. 1, 2012, pp. 53-67.

[4] R. Jannelli, "L'azienda Regione, P. Ricci (a cura di) L' economia Dell'azienda: Paradigmi e Declinazioni,” Giuffrè, Milano, 2012.

[5] E. Caperchione and E.-R. Mussari, “Government Budgeting And Accounting Reform In Italy, AA.VV.-Government, Budgeting and Accounting Reform” Citic Publishing House Beijing (CHN), 2002, pp. 287-311.

[6] M. Meneguzzo, "Ripensare la Modernizzazione Amministrativa e il New Public Management. L'esperienza Italiana: Innovazione dal Basso e Sviluppo Della Governance locale,” Azienda Pubblica, Vol. 10, No. 6, 1997, pp. 587-606.

[7] B. Adam, R. Mussari and J. Rowan, “The Diversity of Accrual Policies in Local Government Financial Reporting: An Examination of Infrastracture, Art and Heritage Assets in Germany, Italy and the UK," Financial Accountability and Management, Vol. 27, No. 2, 2011, pp. 107-133. http://dx.doi.org/10.1111/j.1468-0408.2011.00519.x

[8] L. Canibano and A. Mora, "Evaluating the Statistical Significance of de Facto Accounting Harmonization: A Study of European Global Players," The European Accounting Review, Vol. 9, No. 3, 2000, pp. 349-369.

[9] A. Wildavsky, "The Politics of the Budgetary Process," Brown and Co., Boston, 1974.

[10] P. Onida, “Economia d'azienda,” Utet, Torino, 1971.

[11] L. D’Alessio, "Le Aziende Pubbliche: Management Programmazione Controllo,” Liguori, Napoli, 2008.

[12] E. Anessi Pessina, E. Cantù and N. Persiani, “Armonizzazione Contabile e Revisione dei Bilanci Nelle Aziende Sanitarie Pubbliche,” In: E. Cantù, Ed., Rapporto OASI
2011, L'aziendalizzazione Della Sanità in Italia, Milano, EGEA, 2011, pp. 469-494.

[13] M. S. Giannini, "Autonomia (Saggio sui Concetti di Autonomia),” Rivista Trimestrale di Diritto Pubblico, Vol. II, 1951, pp. 851-883.

[14] S. Cassese and D. Serrani "Regionalismo Moderno: Cooperazione tra Stato e Regioni e tra Regioni in Italia,” Le Regioni, 1980.

[15] F. Amatucci, L'azienda Pubblica and P. Ricci, "L'economia Dell'azienda: Paradigmi e declinazioni,” Giuffrè, Milano, 2012.

[16] Accounting Standards Board (ASB), "Heritage Asset: Can Accounting Do Better?” Discussion Paper, London, 2006.

[17] International Federation of Accountants (IFAC), "International Public Sector Accounting Standards Board (IPSASB)," Elements of the Financial Statements of National Governments, Study 2. US, IPSASB, IFAC, 1993

[18] R. Hodges and H. Mellett, "Reporting Public Sector Financial Results,” Public Management Review, Vol. 5, No. 1, 2003, pp. 99-113.

[19] T. Muller and M. Berger, "IPSAS Explained: A Summary of International Public Sector Accounting Standards," Wiley, Hoboken, 2012

[20] C. Montagna, "Interdipendenza Economica Internazionale e Coordinamento delle Politiche Economiche: Una Rassegna” Rivista Internazionale di Scienze Sociali, Vol. 98, No. 1, 1990, pp. 57-82.

[21] E. Caperchione, R. Mussari and J. L. Chan, "Models of Public Budgeting and Accounting Reform,” OECD, Organisation for Economic Co-operation and Development Paris (FRA), Vol. 2, Suppl. 1, 2002, pp. 305-331

[22] C. Clark, "The Users of Annual Reports of Government Departments," Accountability Symposium, Accounting Association of Australia and New Zealand Conference, New Zealand, July 6, 2002.

[23] A. Bergmann, "The Influence of the Nature of Government Accounting and Reporting in Decision Making: Evidence from Switzerland,” Public Money \& Management, Vol. 32, No. 1, 2012, pp. 15-20.

[24] I. Lapsley, R. Mussari and G. Paulsson, “On the Adoption of Accrual Accounting in the Public Sector: A Self-Evident and Problematic Reform,” European Accounting Review, Vol. 18, No. 4, 2009, pp. 719-723. http://dx.doi.org/10.1080/09638180903334960

[25] A. Bergmann, "Public Sector Financial Management," Prentice Hall Financial Times, Harlow, England, New York, 2009.

[26] F. Capalbo, "Il Contrasto tra Accountability Pubblica e Rendicontazione in Stile Privatistico Nelle Società Partecipate Dalle Pubbliche Amministrazioni,” In: F. Capalbo, Ed., L'applicazione della Contabilità Economica nel Settore Pubblico: Aspettative, risultati e criticità, Giappichelli, Torino, 2012

[27] J. L. Chan, "IPSAS and Government Accounting Reform in Developing Countries,” In: E. Lande and J.-C. Scheid, Eds., Accounting Reform in the Public Sector: Mimicry, Fad or Necessity, 2006, pp. 1-15. 
[28] J. L. Chan, "Government Accounting: An Assessment of Theory, Purposes and Standards" Public Money and Management, Vol. 3, No. 9, 2003, pp. 13-19.

[29] J. Perrin, "From Cash to Accruals in 25 Years," Public Money \& Management, Vol. 18, No. 2, 1998, pp. 7-10.

[30] F. G. Grandis and G. Mattei, "Is There a Specific Accrual Basis Standard for the Public Sector? Theoretical Analysis and Harmonization of Italian Government Accounting,” Open Journal of Accounting, Vol. 1, No. 2, 2012, pp. 27-37.

[31] G. Zanda, "La Grande Impresa. Caratteristiche Strutturali e di Comportamento,” Giuffrè, Torino, 1974.

[32] J. Guthrie, "Application of Accrual Accounting in the Australian Public Sector-Rhetoric or Reality?” Financial Accountability \& Management, Vol. 14, No. 1, 1998, pp. 1-19. http://dx.doi.org/10.1111/1468-0408.00047
[33] F. Aceituno, J. Valeriano, R. Bolivar and M. Pedro, “The Conceptual Framework Concept and the Allocation of Incomes in the Consolidated Entity: Its Impact on Financial Ratios," International Journal of Commerce and Management, Vol. 16, No. 2, 2006, pp. 95-115.

[34] G. Migliaccio "Gli Schemi di Rendicontazione Economico-Patrimoniale Degli Enti Locali. Evoluzione, Comparazioni e Prospettive,” Milano, FrancoAngeli, 2010, pp 139-167.

[35] R. Jannelli, "Le Garanzie Offerte Dalla Revisione nei Sistemi di Contabilità Economica,” In F. Capalbo, Ed., L'applicazione Della Contabilità Economica nel Settore Pubblico: Aspettative, Risultati e Criticità, Giappichelli, Torino, 2012, pp. 243-268.

[36] W. Goethe, "Die Wahlverwandtschaften,” J. G. Cottaische Buchhandlung, Berlin, 1809. 